\title{
THE BODY INSIDE-OUT: ANATOMICAL MEMORY AT MAUBUISSON ABBEY
}

This article is due to appear in the journal Art History in April 2019

\begin{abstract}
:
The now destroyed Abbey of Maubuisson, situated just northwest of Paris, was a religious foundation that over the centuries crafted a uniquely visceral visual culture. By charting a long history of the institution from its medieval foundation to its early modern demise, this article looks to Maubuisson's bodies - figures formed of painted wood, marble, gilded copper, and raw preserved flesh - in order to unearth a long-standing proclivity at the abbey for flipping the human form inside-out. Maubuisson brings to light a new context with which we might begin to read medieval and early modern objects: a case study in the folding together of medicine, religious ritual, and sculpture into a distinctive form of institutional, anatomical memory.
\end{abstract}

\section{ARTICLE:}

Maubuisson Abbey no longer exists. Built between 1236 and 1244, the foundation was systematically dismantled some 550 years later in 1792 when between 8th September and 10th December forces loyal to the French Revolution forcibly ejected its few remaining nuns from their quarters and removed or destroyed almost all of its fixtures and fittings. The abbey's thirteenthcentury church was found to have a detrimental effect on the value of the land and soon after was razed to the ground, the once great Cistercian institution reduced to rubble and flipped for profit. Any historical engagement with Maubuisson quickly comes up against the problem of its scant remains: a flat lawn where mossy remnants of carved stone poke up through the grass and daisies (fig. 1).

A handful of scholars have tried to deal with this loss, each in their own different way. For Adolphe Dutilleux and Joseph Depoin, writing in the 1880s, a forensic textual historiography was the key, combing through the abbey's surviving charter, account-books, and inventories to slowly 
form an image of Maubuisson as recorded on parchment and paper. ${ }^{1}$ In the late 1970s, Terryl Kinder turned instead to a more projected form of reconstruction as she re-pieced elements of the abbey's relatively austere architectural style. ${ }^{2}$ And by the 1980 s, trowels were trumping typewriters to attempt a more literal excavation of Maubuisson's past. Archaeological digs there revealed an extensive sewer system, pottery shards, and fragmentary bones beneath the abbey's settled earth. ${ }^{3}$

My interest in Maubuisson, by contrast, lies in a more insistent process of revivification. By this I do not simply mean an abstracted, historical revival of the abbey following its unfortunate demise, although I do aim to suture the site from its medieval foundations through to its early modern end. Rather, I am more intrigued by a series of unusual encounters at the very heart of Maubuisson's material history which themselves pose the foundation's fluctuating status between presence and absence in a more corporeal sense. In what follows, I want to track Maubuisson's bodies. These are figures formed from a diverse profusion of materials - painted wood, marble, gilded copper, raw preserved flesh - but which when drawn together exhibit a consistent and pressing concern at the abbey for flipping human forms inside-out. In its intertwining of anatomy and aesthetics, Maubuisson offers a new lens through which to view both the body and its sculpted likeness in the medieval and early modern world: the uncanny idea of an institutional, anatomical memory.

\footnotetext{
I would like to thank the editors and anonymous reviewers of Art His tory for their support and helpful feedback. Invaluable to my thinking about objects at Maubu isson has been many conversations over earlier drafts with Antony Eastmond, Robert Mills, Barbara Baert, Jos eph Ackley, and Simon Dell, as well as kind invitations to present this material in lectures at Princeton, Durham, St Andrews, and UEA.

${ }^{1}$ Adolphe Dutilleux and Joseph Depoin, L'Abbaye de Maubuisson: Histoire et Cartulaire, Pontoise, 1882.

${ }^{2}$ TerrylN. Kinder, 'Blanche of Castile and the Cistercians: An Architectural Re-Evaluation of Maubuisson Abbey', Cîteaux, 27, 1976, 161-188. I am indebted to M. Jean-Yves Ricordeau of Revue Cîteaux for making this article available to me.

${ }^{3}$ On the abbey's archaeological history, see Monique Wabont et al, 'Les Fouilles de l'Abbaye de Maubuisson (19781983)', in Benoît Chauvin, ed., Actes du Congress Anselme Dimier, Abbaye de Noirlac: Fouilles Cisterciennes Européennes Bilans Nationaux, I. France, Pupillin, 2000, 123-154. On its painstaking partial reconstruction, see Phillipe Soulier, Restauration à l'Abbaye Royale et Cistercienne de Maubuisson, Saint-Ouen-l'Aumône, 1988; Armelle Bonis and Monique Wabont, L'Abbaye de Maubuisson, Rennes, 1997.
} 


\section{Opening}

Maubuisson's geography provides a neat segue into this corporeal mode of thinking, for the abbey was founded just half a day's journey to the west of Paris, a city which in many ways exemplifies the dynamic yet contradictory potential of the body for French intellectuals and artisans in the later Middle Ages and beyond. In particular, Paris played host to a growing collection of medical evidence - literary, visual, and performative alike - that attested to a simultaneous fixation with and distain for bodily interiors, a tension which fascinated and unsettled contemporary Frenchmen in equal measure.

Take, for instance, a scene described in the fifteenth-century diary of the notary Jean de Roye, clerk of the Châtelet, Paris' lowest centralised court housing various organs of bureaucracy, police barracks, and a series of dank prisons dug increasingly deep into its flood-prone basements. Jean's daily tasks revolved around the preservation of an accurate record, from obligations of bail to the issuance of written credit, which is why one of his journal entries strikes us with particular alarm. In January 1475 , Jean records that the body of a man was incised at the stomach for internal inspection by a group of medical experts. ${ }^{4}$ The patient, if we can call him that, was a franc-archer from Meudon, an infantryman who had been imprisoned in the Châtelet for larceny and sentenced to hang at the city's largest gibbet at Montfaucon. But, Jean writes, on the day of the man's proposed hanging a petition was submitted to King Louis XI by a group of physicians and surgeons of the city who believed the body of the condemned may be of some use. Invoking various common conditions - bladder stones, burning colic, and other painful internal maladies - the practitioners suggested it would be of great help for them in their diagnoses to 'see the sites where these diseases are formed in the human body, the best way of doing so being to cut open the body of a living

\footnotetext{
${ }^{4}$ Jean's journal, sometimes known as the ChroniqueScandaleuse, is preserved in two manuscripts: Paris, Bibliothèque nationale de France, MS Français 5062 (where the surgical account begins on fol. 103r) and Français 2889 (with the account beginning on fol. 133v). The most recent translation is Jean de Roye, Chronique Scandaleuse, Journal d'un Parisien au temps de Louis XI, trans. Joël Blanchard, Paris, 2015.
} 
man'. ${ }^{5}$ The petition was successful and Jean goes on to record the man's 'opening and incision in the appropriate place' ('...laq[ue]lle ouverture et incision fut faicte ou corps'), the examination of different potential points of disease, and the archer's body being 'restitched and his entrails placed back inside' ('...fut recousu et ses entrailles remises dedens'). Given the finest recuperative care at the king's expense, the soldier made a full recovery within a fortnight, had his sentence of death pardoned, and was even compensated handsomely for his troubles.

Much of this account seems extremely strange to a reader today: the royal petition by an interrogative band of medics, the archer's speedy and seemingly untroubled recovery from what must have been substantial bodily trauma, and especially the way Jean frames the vivisection as a semi-public spectacle. As Vivian and Christine Nutton have carefully shown, Jean's literary sources and motivation are sound; he offers a particularly dispassionate account of events and stands well appraised of contemporary medical mores and vocabulary. ${ }^{6}$ Yet such an overtly anatomical act was nonetheless highly atypical by medieval Parisian standards, even in the late fifteenth century. Gradual developments in southern Europe over the previous three centuries had seen sustained discussions of the body's interior re-emerge into medical discourse for the first time since late antiquity, especially in Italy where the work of university physicians - foremost the Bolognese practitioner Mondino dei Liuzzi - attests to annual anatomies of corpses in the city as early as 1315. In non-academic contexts as well, late medieval Italians were slowly reengaging with internal forms, opening bodies as part of legal examinations and funerary rites. ${ }^{8}$ Evidence from Paris, however, makes clear that such ideas were more problematic for contemporary Frenchmen.

\footnotetext{
5 ‘...veoir les lieux ou lesdictes maladies sont concrees dedens les corps humains, laquelle chose ne pouoit mieulx estre sceue que inciser lecorps dun homevivant'.

${ }^{6}$ Vivian and Christine Nutton, 'The Archer of Meudon: A Curious Absence of Continuity in the His tory of Medicine', Journal of the History of Medicine and Allied Sciences, 58: 4, 2003, 401-427.

${ }^{7}$ For an important early translation of the Anatomia, see Lino Sighinolfi, ed, Anatomia. Riprodotta da un Codice Bolognese del Secolo XIV e Volgarizzata nel Secolo XV, Bologna, 1930. For a general introduction to Mondino and anatomical his tory, especially in Italy, see Andrea Carlino, La Fabbrica del Corpo: Libri e Dissezionenel Rinascimento, Turin, 1994.

${ }^{8}$ This has been dis cussed extensively in the work of Katharine Park, es pecially The Secrets of Women: Gender, Generation, and the Origins of Human Dissection, New York, 2006 (and the extens ive bibliography therein). See als o Katharine Park, 'The Life of the Corpse: Dis section and Division in Late Medieval Europe', Journal of the Historyof Medicine and Allied Sciences, 50, 1995, 111-132.
} 
Ongoing social tensions between the capital's theoretically-minded physicians and more practicallyoriented surgeons, coupled with longer-standing religious hostility towards medical openings of the body, had led to doctors at Paris' university being forbidden from undertaking formal anatomies in the same manner as their Italian counterparts. ${ }^{9}$ One particularly stringent academic regulation from 1408 even ruled that a surgeon, Jean de Pise, who had recently achieved the status of master physician through the university, should abandon his manual practice altogether, stating 'it would be dishonourable for a medical master to carry out manual activity, as this has never been done at the University of Paris'. ${ }^{10}$ Avoidance of anatomical investigations in the upper echelons of the medical elite does not, of course, mean that the city was medically inert by any means; the detailed studies of Danielle Jacquart and Michael McVaugh among others have highlighted the diversity of the city's healthscape, nourishing in particular a number of skilled surgical practitioners, several of whom proved talented writers and advocated for the elevation of their often intellectually-spurned craft. ${ }^{11}$ Nonetheless, it was not until the mid 1490s that anything approaching the observational anatomy of the franc-archer would be formally undertaken by the Parisian medical faculty, and even then such events appear irregularly in the city's records until some way into the sixteenth century.

The conflicted push and pull of this broader Parisian situation can be read between the lines of Jean's account. Simultaneously present are both an intense eagerness to open the archer from Meudon - to actually look beneath the surface, to see first-hand the genesis of illness - and the opposing strictures which heavily regulated such internal observation, tacitly accounted for in the

\footnotetext{
${ }^{9}$ On the social tensions between physicians and surgeons in Paris, see Michael McVaugh, The Rational Surgery ofthe Middle Ages, Florence, 2006. On religious concerns, see: Ynez Voilé O’Neill, 'Innocent III and the Evolution of Anatomy', Medical History, 20: 4, 1976, 429-433; Elizabeth A. R. Brown, 'Death and the Human Body in the Later Middle Ages: The Legis lation ofBoniface VIII on the Divis ion of the Corpse', Viator, 12, 1981, 221-270.

10 'Inhonestum fore magistrum in medicina manualiter operari, considerato quod hoc nunquam visum est in isto studio Parisiensi'. As transcribed in Ernest Wickersheimer, ed, Commentaires de la Faculté de Médecine de l'Université de Paris (1395-1516), Paris, 1915, 47. The stringency of such rules have been questioned by his torians, but these statements s till attes to the sentiments of university administrators. See Park, Secrets of Women, $53 \mathrm{ff}$.

${ }^{11}$ See, for example, Danielle Jacquart, La Médecine Médiévale dans le Cadre Parisien, Paris, 1998 (and the extensive bibliography on Paris ian medicine therein); Cornelius O'Boyle, The Art of Medicine: Medical Teaching at the University of Paris, 1250-1400, Leiden, 1998; Michael McVaugh, 'Medicine and Arts in Thirteenth-Century Paris', in Spencer E. Young, ed., Crossing Boundaries at Medieval Universities, Leiden, 2011, 189-212; McVaugh, The Rational Surgery.
} 
uncustomary royal petition and granting of the king's consent. Clearly there was disagreement, or at least indecision, as to where the body's limits sat both anatomically and socially, something also attested in visual evidence from this same late medieval Parisian moment. Particularly potent in this regard is a mid-fourteenth-century manuscript written and illustrated in the capital containing a commentary by Albertus Magnus on Aristotle's De animalibus. ${ }^{12}$ As we might expect for a relatively large and luxurious edition of a popular text, its pages are embellished with pen flourishes, illuminated initials, and even occasional marginal scenes, framed with floral motifs and inhabited by the text's eponymous animals feeding, fighting, and rutting. Folio 176r, however, pictures no frolicking birds, nor deer galloping across its bas-de-page; instead, beneath the introduction to Albertus' Book 13 on the internal members of living creatures, sits an enlarged gathering of bodily organs arranged as if within a living human form (fig. 2). We are able to follow the long trachea downwards towards the lungs and intestines, atop of which sit the liver, heart, stomach, bladder, and kidneys - each of which are also shown floating to left and right, enlarged and abstracted - while at the base of the entire system a tubular colon and anus morph seamlessly into twin branches of floral decoration.

There is an overwhelming sense of bodily revelation here. The skin has been disappeared affording a deep view of the innards to be discussed by Albertus in the coming folios, a particularly accurate rendering by contemporary standards. But the page also emphatically presents the act of autopsical observation itself. The bodily arrangement is flanked by a crowd of six physicians, deliberately identifiable by their doctoral gowns and bonnets, all of whom perform the exact opposite of the purported disdain for viewing the interior to be read in the regulations of their university. Each stares up at the gigantic organs with frantic and awed gesticulations. They are presented less as figures bound by strict institutional guidelines and more like those described by Petrarch in his contemporary caricature of Italian physicians and what he dubbed their 'obsessive

\footnotetext{
${ }^{12}$ The manus cript was originally in the collections of the Collège de Sorbonne and is now Paris, Bibliothèque nationale de France, MS Latin 16169. On the manus cript's place in the Albertian tradition, see Amandine Postec, 'Un Exemplaire Singulier du De animalibus d'Albert le Grand et son Illustration', Reinardus, 26, 2014, 137-160.
} 
seeing'. 'They claim', he admonishes in a volley of invective, 'to see that which lies within the viscera and tissues? They can't even see what's before their very eyes!'13 Like Jean's revivified archer from Meudon, the miniature is a reminder that late medieval evocations of the opened body inevitably served multiple complex functions at once, bound up with conflicting attitudes towards vision, knowledge, and the innards. Indeed, these are not only Parisian ideas. They offer a route into events just twenty short miles away to the northwest at Maubuisson.

\section{The Maubuisson Madonna}

By the middle of the thirteenth century, the site at Maubuisson had transformed significantly from the former bandit hideaway which had earned it a name derived from 'buisson maudit', literally 'bad bush' (fig. 3). This was primarily the work of one woman, Queen Blanche of Castile, an extremely significant figure in thirteenth-century French politics who ruled the country as regent in the stead first of her deceased husband, Louis VIII, and later her crusading son, Louis IX, the soon-to-be Saint Louis. ${ }^{14}$ Particularly deft in her statecraft, Blanche was also no stranger to the social conventions of royal patronage. As well as a host of newly-authored religious texts and decorated books dedicated in her honour, the queen supplied funds for the building of three major institutions established under the order of Citeaux: the abbey of Le Lys to the south-east of Paris, and to the north-west the abbeys of Royaumont and, her favourite, Maubuisson, founded as NotreDame-la-Royale. ${ }^{15}$ Building was begun there the week after Pentecost in 1236 and by 1241 the site

\footnotetext{
${ }^{13}$ 'Et vis videre quidin imo viscerum ac fibrarum lateat?' Quod est ante oculos non vides'. Petrarch, 'Invective contra medicum II', in Petrarch, Invectives, ed. David Marsh, Cambridge, 2003, 78.

${ }^{14}$ The most recent and extensive work on Blanche is Lindy Grant's excellent biography, Blanche of Castile, Queen of France, New Haven, 2016. Her period as Queen Regent has been highlighted in various studies of medieval royalty and kingship: Claudia Zey, ed., Mächtige Frauen? Königinnen und Fürstinnen im europäischen Mittelalter, Ostfildern, 2015; Éric Busman et al, eds, Femmes de Pouvoir: Femmes Politiques durantles derniers siècles du Moyen Âge et au cours de la Première Renaissance, Brussels, 2012; Therese Martin, ed., Reassessing the Role of Women as 'Makers' of Medieval Art and Architecture, Leiden, 2012; Kathleen Nolan, ed., Capetian Women, New York, 2003; Anne J. Duggan, ed., Queens and Queenship in Medieval Europe, London, 2002; June Hall McCash, ed., The Cultural Patronage of Medieval Women, A thens GA, 1996.

${ }^{15}$ On Blanche's patronage generally, see: Alexandra Gajews ki, 'Blanche of Castile: The Patronage Question Under Review', in Martin, Women as 'Makers', 197-244; Constance H. Berman, 'Two Medieval Women's Property and Religious Benefactions in France: Eleanor of Vermando is and Blanche ofCastile', Viator, 40: 2, 2010, 151-182;
} 
was ready to acommodate its first inhabitants, nuns selected from the Parisian centre of SaintAntoine-des-Champs whose presence cemented the foundation's direct connection to the capital. ${ }^{16}$ The abbey's church was finally dedicated by the Bishop of Paris, Guillaume d'Auvergne, on 26 June 1244 and from then on it enjoyed significant favour with the Crown. ${ }^{17}$ After just two years, the abbey and the nearby Palace Royale at Pontoise had already received King Louis IX and the royal court on multiple occasions, assorted generations of the royal family, various cardinals, bishops, and archbishops of France, and a long list of foreign dignitaries including Pope Innocent IV, the patriarchs of Antioch and Constantinople, and the Latin Emperor of Jerusalem. ${ }^{18}$

It will always be possible to elaborate the site further through this overflowing stream of important figures, or by dissecting other historical moments that feature Maubuisson as backdrop: Blanche's brokering of the Lusignian succession at the abbey, the familial politics of appointing the foundation's early abbesses, even the nearby landscape's well-recorded abundance of leeks. Other histories, however, are allowed to come to the fore when we focus our attention away from gentry and guest-lists and onto objects. In turning to Maubuisson's bodies, I want instead to take as an anatomical mascot one of the earliest known artworks to have been produced for the foundation, a sculpture now lost of the Virgin and Child. Stolen in 1973 from the nearby parish church of SaintOuen-l'Aumône, it is sadly yet to resurface. But its callous theft fits neatly into a much longer history of occluded presence and corporeal revelation that has continuously surrounded the institution from its earliest days.

\footnotetext{
Tracey Chapman Hamilton, 'Queenship and Kinship in the French “Bible Moralisée”: The Example of Blanche of Castile and Vienna ÖNB 2554', in Nolan, Capetian Women, 177-208.

${ }^{16}$ For a short yet detailed outline of the foundation's early history see Grant, Blanche of Castile, 118ff. She notes that the purchase of land and construction of the abbey was largely overseen by the royal administrator Master Richard of Tourny, although Blanche appears to have taken a close personal interest as evidenced by the contents of the $A c h a t z$ $d$ 'heritage, a book written by Tourny recording the abbey's early history and accounts. The Achatz survives as Pontoise, Archives Départementales du Val-d'Oise, 72H12, with translations in Henri de L'Epinois, 'Comptes Relatifs à la Fondation de l'Abbaye de Maubuisson', Bibliothèque de l'École des Chartres, XIX, 1858, and Constance H. Berman, Women and Monasticism in Medieval Europe: Sisters and Patrons of the Cistercian Reform, Kalamazoo, 2002.

${ }^{17}$ Maubuisson's charter is dated March 1241, now Ponto ise, Archives Départementales du Val-d'Oise, 72 H115.

${ }^{18}$ Louis and his court vis ited approximately 48 times according to L'Abbé Trou in Recherches Historiques, Archéologiques et Biographiques, sur la Ville de Pontoise, Pontoise, 1841, 63. A sixteenth-century account of the area is included in F. Nöel Tailepied, Les Antiquitiés et Singularités de la Ville de Pontoise, 1587, Paris, 1876.
} 
Several sources help us reconstruct the sculpture's likeness. A three-quarter image taken at some point between 1920 and 1936 as part of the Foto Marburg cataloguing project shows the Virgin seated, dressed in a veil and flowing robe (fig. 4). Her right hand is outstretched, its curved fingers the only palimpsest of a lost original object once in her grasp, perhaps a sceptre, while her left hand supports the young Christ. A colour photograph which today hangs like a memorial on the walls of the church at Saint-Ouen makes clear the soft polychromy of the sculpture's skin and its ornate golden throne (fig. 5). A pair of commemorative postcards from c.1910 and c.1970 give a further sense of the contrasting poses of Mother and Child (figs 6-7). The Virgin is placid, her eyes open staring straight ahead, while Christ hovers awkwardly above her knee, his neck jutting high above the shoulders and sporting the wiry pose of a figure more shrunken man than child. He seems contrastingly alert in both pose and expression, his right arm raised in a sign of benediction that adds to a sense of boney upwardness in the child. Together, these photographs constitute the entirety of the sculpture's visual record. An Interpol Theft Report distributed on its disappearance adds only a few further details: an unknown artist, carved from a continuous walnut block, a height of $140 \mathrm{~cm}$, slightly larger than life-size given the Virgin is seated. ${ }^{19}$

Even from these meagre images, though, we can tell something strange is afoot. A thick line ruptures the otherwise peaceful scene, a black gap running from the top of the Virgin's head straight down through the sculpture right to its base. She is not a hermetically rendered figure, but is constructed of corresponding halves: small hinges subtly concealed within the throne's side panels allows her to be opened in two, whereupon the interior of the Virgin's body reveals a microarchitectural scheme inhabited by twenty-one smaller figures, including saints, angels, the dove of the Holy Spirit, and the crucified Christ (fig. 8). The sculpture is a Shrine Madonna. Also known as Triptych Virgins, Vierges ouvrantes, Schreinmadonnen, or Virgenes abrideras, around 70 such pieces are attested from the twelfth to seventeenth centuries, spread geographically across Europe from Spain in the West to Sweden in the North and the Polish-Lithuanian Commonwealth

\footnotetext{
${ }^{19}$ Interpol, 'Theft of Cultural Property: A Report by the Interpol General Secretariat to the Organization's Forty-Second General As sembly, 2-9 October 1973', Museum, 26: 1, 1974, 4-9.
} 
in the East, as well as several in Latin America. ${ }^{20}$ Despite their small number they are extremely diverse. The exact pose and style of the Virgin varies from seated, to standing, to alone, to with Child; they can be small and easily portable, or monumentally large; they can be intricately carved or simply decorated, excessively coloured or naturalistically painted; they can hinge only at the chest, can split from the neck down, or can be fully bisectable; and the Virgin's body might open to reveal internal facets sculpted in deep relief, often depicting the Trinity, or alternatively display flatter, painted surfaces detailing narrative moments in the life of Christ or the Virgin herself. They are a slender but busy corpus.

The only consensus currently reached on the Madonna stolen from Saint-Ouen-l'Aumône is that it was originally made for the church at Maubuisson. Abbey accounts of 1517 note a series of payments to a local painter for restorations undertaken to a long list of the foundation's most important spaces and objects, including this 'gold and azure' sculpture of Our Lady. ${ }^{21}$ That the Shrine Madonna was in need of work at this point suggests it had been in existence for some time, an idea that resonates too with a uniquely spry and gossipy account written at some point between 1628 and 1646 by one Soeur Candide, a nun at Maubuisson and confidante of the recently arrived Abbess, Marie Suireau de Rocheren. ${ }^{22}$ As well as charting the convoluted history of the sculpture's relocation within the abbey church, Candide states that it had been made several hundred years

\footnotetext{
${ }^{20}$ The most recent and wide-ranging study of the Shrine Madonna is Elina Gertsman, Worlds Within: Opening the Medieval Shrine Madonna, University Park PA, 2015, which contains a full bibliography. Other studies include: Irene González Hernando, El arte bajomedieval y su proyección: Temas, funciones y contexto de la Vírgenes abrideras tríptico, Madrid, 2011; Melissa R. Katz, 'Interior Motives: The Vierge Ouvrante/Triptych Virgin in Medieval and Early Modern Iberia', doctoral thesis, Brown University, 2011; Marius Rimmele, 'Die Schreinmadonna: Bild-Körper-Matrix', in Kristin Marek et al, eds, Bild und Körper im Mittelalter, Munich, 2006, 41-59; Gudrun Radler, Die Schreinmadonna Vierge Ouvrante: Von den bernhardinischen Anfängen bis zur Frauenmystik im Deutschordensland, Frankfurt, 1990; Renate Kroos, 'Gotes Tabernackel: zu Funktion und Interpretation von Schreinmadonnen', Zeitscrift für schweizerische Archäologie und Kunstgeschichte, 43, 1986, 58-64; Édouard Didron, 'Les Images Ouvrantes', Annales Archéologiques, 26, 1869, 410-421.

21 'Avons fait peindre par un peintre de Paris l'image Notre-Dame, appellée Notre-Dame-la-Royalle, ensemble la clôture, chapiteau, et pied d'icelle toute doréeet azurée...' Dutilleux and Depoin, L'Abbaye de Maubuisson, 100. The renovation and its restoration of the Madonna into the minds of Maubuisson's inhabitants might also account for an image very similar to the sculpture appearing on a seal of the abbey produced around 1524. See Solenne Théaud, 'Les Sceauxdu Chartrier de l'Abbaye Cistercienne de Maubuisson au XIIIe Siècle', Cîteaux, 54: 1, 2003, 102.

${ }^{22}$ Soeur Candide, 'Relations de la conduite particulière de chaque abbé et religieuxqui ont eu part à celle de Maubuisson, et des traverses qu' ils ont faites à la Mère des Anges pendant 22 ans, dans lesquelles on voit la vertu, la sagesse et la grande humilité de cettemere', c.1628-1646, now Paris, Bibliothèque Mazarine, MS 3369 (formerly MS 2983A), 17th relation, fol. 250ff. Transcribed in Joseph Depoin, 'La Vierge Ouvrante de Maubuisson', Mémoires de la Société Historique et Archéologique de l'Arrondissement de Pontoiseet du Vexin, vol. IV, Paris, 1883, 17ff.
} 
before 'through the devotion of an Abbess'. ${ }^{23}$ Direct comparisons for nuancing this date are slim; no other Parisian Shrine Madonna has been known to the modern world and the few which seem to have once existed are described only in fragmentary textual sources. ${ }^{24}$ Without such sister works, commentators have instead turned to a particularly strong local tradition that placed the Madonna as far back as Maubuisson's foundation and the patronage of Blanche in the 1240s. A thirteenthcentury date would certainly find contemporary resonance in the iconic pose and features of Mary's face, the rounded arms of her throne, and the quatrefoil motif at the sculpture's base. ${ }^{25}$

The specific function of the sculpture at Maubuisson is similarly difficult to pin down, a problem for all Shrine Madonnas given their variations in location, size, and content. Candide's account accords the piece a prominent role in the ritual life of the foundation, noting it was placed on the abbey church's high altar, regularly processed around the nearby town of Pontoise, and opened in particular to pray 'for water in times of drought'. ${ }^{26}$ This chimes with the sculpture's tactile forms, its distinctive opening body suggesting a host of parallels with various liturgical objects designed to engage individuals with increased vividness through their direct manipulation; larger Shrine Madonnas have been likened to triptych altarpieces, while smaller versions seem more immediately akin to personal altars or Books of Hours. ${ }^{27}$ Viewed through a theological lens, these hinging bodies certainly echo longstanding Marian doctrine in prayers and psalms which describe

\footnotetext{
23 ،...l'on disoit avoir été faite, il y avoitenviron deux cents ans, par la devotiond 'une abbesse'.

${ }^{24}$ These include an ivory example from Notre-Dame Cathedral(according to a 1342 inventory, 'quedam alia imago eburnea valde antiqua scisa per medium et cum imaginibus sculptis in apertura, que solebat poni super magnum altare', Gustave Fagniez, 'Inventaires du Trésor de Notre-Dame de Paris. Suite 1: Inventaire de 1342', Revue Archéologique, 27, 1874, 251); another which prompted strong critique in a sermon by Jean Gers on(Jean Gerson, 'Sermo de nativitate domini', in Louis Ellies Du Pin, ed., Opera Omnia, Hildes heim, 1987, vol. 3, col. 947; a third in a Carthusian monastery nearby (attested in Johannes Molanus, De pictures et imaginibus sacris, Louvain, 1570, although perhaps the same sculpture cited by Gerson); and a fourth in the Royal Oratory of the Grand Tower at Bois de Vincennes.

${ }^{25}$ See, for example, the frontal stance and placid face of the ivory Madonna and Child, late thirteenth-century, now in the Museo Nazionale delBargello, Florence (Inventory number: $88 \mathrm{C}$ ); the extremely similar throne and clothing of the wooden Madonna and Child form Oignies, c.1210-20, now at the Metropolitan Museumof Art (Accession number: 41.190.283); and the same quatrefoil-patterned base of the ivory Virgin of the Sainte-Chapelle, late thirteenth-century, now in the Louvre (Object number: OA 57).

26 ،...pour avoir de l'eau dans le temps de sécheresse'. Candide speaks of children who would throw nuts and fruit at the sculpture 'in procession or otherwis e'. She locates the sculpture behind the high altar, perhaps on the later 'Friars' Altar' which TerrylKinder situates slightly to the east. Kinder, 'Blanche of Castile and the Cis tercians', 181.

${ }^{27}$ Gertsman, Worlds Within, esp. 101ff; Marius Rimmele, Das Triptychon als Metapher, Körper, und Ort: Semantisierungen eines Bildträgers, Munich, 2010, 107-193; Elina Gertsman, 'Image as Word: Visual Openings, Ocular Readings', Studies in Iconography, 32, 2011, 51-80.
} 
the Mother of God as an openable oven, doorway, or portal. ${ }^{28}$ Some commentators have gone even further to present the sculptures as artefacts of a more internalised and voyeuristic streak in medieval culture, convincingly drawing links with the distinctly anatomical concerns of many Christian ritual bodies from contemporary abstractions of the Virgin's holy uterus to the divided figures of the saints. ${ }^{29}$ So clear were these bodily evocations to the objects' original audiences that their commissioning was on occasion aggressively preached against by contemporary theologians. Jean Gerson, for instance, disliked the sculptural implication that Mary birthed not just Christ but the full godhead and panoply of saints revealed inside her wooden belly; he attempted to enforce a ban on Shrine Madonnas, although their restriction seems to have fallen on deaf ears for a faithful populous clearly captivated by the beguiling unfolding of their Matryoshka-like forms. ${ }^{30}$

Like Gerson, such bodily readings also find their detractors in the contemporary literature. Seeing the Shrine Madonna's fractured world of subdivided figural and architectural interiors as foregoing, even erasing, the once organic body of the closed sculpture, some are more comfortable with a rhetoric of pure function that turns these works, once opened, into pieces of super-human (or sub-human) liturgical furniture. Melissa Katz, for example, distils this argument down to matters of appropriateness: the action of the Shrine Madonna, she says, 'is not a cruel dismemberment... [it] emphasises her compassion rather than participation in violent torment and physical affliction'. ${ }^{31}$ But it is important to remember that by the later Middle Ages such corporeal aggression had become a powerful rhetorical device in Christian worship, from the vulnerable and bloody flesh of

\footnotetext{
${ }^{28}$ Kroos, 'Gotes Tabernackel'; Melissa R. Katz, 'Behind Closed Doors: Dis tributed Bodies, Hidden Interiors, and CorporealErasure in Vierge Ouvrante Sculpture', RES, 55/56, 2009, 194-221; Melis sa R. Katz, 'Marian Motion: Opening the Body of the Vierge Ouvrante', in Nino Zchomelidse and GiovanniFreni, eds, Meaning in Motion: The Semantics of Movement in Medieval Art, Princeton, 2010, 63-91.

${ }^{29}$ Gertsman, Words Within, esp. 57ff; Elina Gertsman, 'Performing Birth Enacting Death: Uns table Bodies in Late Medieval Devotion', in Elina Gertsman, ed., Visualizing Medieval Performance: Perspectives, Histories, Contexts, Burlington, 2008, 83-104; Elina Gertsman, 'Pilgrim's Progress: Devotional Journey Through the Holy Womb', in Sarah Blick and Laura D. Gelfand, eds, Push Me, Pull You: Imaginative, Emotional, Physical, and Spatial Interaction in Late Medieval and Renaissance Art, Leiden, 2011, vol. 2, 231-259; As safPinkus, Sculpting Simulacra in Medieval Germany, 1250-1380, Farnham, 2014, 149-178.

${ }^{30}$ On the ban seeGertsman, Words Within, especially 'Introduction', $1 \mathrm{ff}$.

31 Katz, 'Interior Motives', 324ff.
} 
Christ and the saints to the divided bodily relics required of every consecrated church. ${ }^{32}$ Moreover, the idea that the immediacy of the Shrine Madonna's body can ever be transcended, that in some way it disappears once opened, is especially problematic when we return from abstract theology to the works themselves. The Maubuisson Madonna, for instance, even when fully open, presents the viewer with snatches of strangely severed fleshly parts: Christ's arm juts out from behind the right side of the body, mid-benediction; the isolated fingers of the Virgin's right hand grasp from the sculpture's side; Mary's face is not dissipated but doubled, split into twin profiles in silhouette across each wing. If anything, the open sculpture evokes a bodily multitude not a bodily absence. It was a singular and unusual body that like an anaesthetised Prometheus could at any moment enact a strange but enchanting shift between gaping and shut states, an eternally emergent subject constantly being formed and reformed from a multiplicity of corporeal elements.

Most importantly, such anti-body thinking also presupposes that religious foundations could not themselves be places of literal bodily invasion and display. This is where the sculpture's location at Maubuisson begins to play a particularly illuminating role. For there in the abbey, the body of the Shrine Madonna was enabled to channel more than just abstract metaphors of opening. It was set into dialogue with its immediate environs, a space where the excarnated human body was wrought into the very fabric of the institution itself.

\section{Blanche's Heart}

The foundation of three Cistercian abbeys, including Maubuisson, must have held particular significance for Blanche of Castile. Not only did she disburse significant expense on these foundations -24,432 livres on Maubuisson alone between 1236 and 1242, including the building of her own personal mansion on its grounds - but they also continued a strong lineage of women's

\footnotetext{
${ }^{32}$ For two good introductions to this much-discussed idea, see: Valentin Groebner, Ungestalten: Die visuelle Kultur der Gewalt im Mittelalter, Munich, 2003; Caroline Walker Bynum, 'Violent Imagery in Late Medieval Piety', German Historical Institute Bulletin, 30, 2002, 3-36.
} 
dynastic patronage within her family. ${ }^{33}$ Blanche's grandmother, Eleanor of Aquitaine (d.1204), had retired to her own Benedictine foundation at Fontevraud in Poitou, and Blanche's mother, Leonor of England (d.1214), also retired to the abbey of Santa María la Real de Las Huelgas in Burgos, an institution she had founded in $1189 .{ }^{34}$ These abbeys, all endowed by queens, acted as centres for women's worship, education, and care, but they also constituted extremely effective royal necropolises to promote ongoing dynastic power. Eleanor and Leonor, as well as Blanche's sister Berenguela of Castile (d.1246) who also supported Las Huelgas, were all interred within their foundations, and Blanche herself chose Maubuisson as the best place for burial upon her death. However, the treatment of Blanche's body in the lead up to this event was far from typical in comparison with the memorialisation of her fellow royal women. Not only was Blanche Maubuisson's founder, she was also the architect of a specifically anatomical instinct within the abbey's church.

The funeral of Blanche is the only one of a French medieval queen to be substantially documented by contemporaries, although while this strong record bears testimony to the mark she had made on her countrymen over the previous half-century, their evidence can at times be contradictory. Charles of Anjou, Blanche's son, puts his mother's place of death directly at Maubuisson, however other contemporary witnesses including the chroniclers Primat of Saint Denis and Guillaume de Saint-Pathus all closely narrate a longer and somewhat more feasible account. ${ }^{35}$

\footnotetext{
${ }^{33}$ On the detail of Blanche's spending at Maubuisson seethe summary and sources in Grant, Blanche of Castile, 118119. On Cistercian foundations and women more generally, see Bernadette Barrière and Marie-Elis abeth MontuletHenneau, Cîteaux et les Femmes: Architectures et Occupation de l'Espace, Grane, 2001.

${ }^{34}$ On the patronage of this dynasty, see Miriam Shadis, 'Piety, Politics, and Power: The Patronage of Leonor of England and Her Daughters Berenguela of León and Blanche of Castile', in McCash, Medieval Women, 202-227.

${ }^{35}$ Phillipe Delorme, Élie Berger, and others rightly question later testimony from the funeral of Saint Louis that she died at Maubuisson. Several sources rely solely on such accounts and thus suggest, wrongly, that she died at the abbey. See: Phillipe Delorme, Blanche de Castile, Paris, 2002, 314-316; Élie Berger, Histoire de Blanche de Castile Reine de France, Paris, 1895. Charles of Anjou's testimony is recorded in M. le Comte Riant, 'Déposition de Charles d'Anjou pour la canonisation de Saint Louis', Notices et Documents Publiés pour la Société de l'Histoire de Franceà l'Occasion du Cinquantième Anniversaire desa Fondation, Paris, 1884, 155-176; Primat in his Chronique, translated by Jean de Vignay and preserved in London, British Library, Royal MS 19 D I, fol. 192v-251v (transcribed and edited as 'Chronique de Primat' in Recueil des Historiens des Gaules et de la France [hereafter RHGF], 23, Paris, 1844, 10); and Guillaume de Saint-Pathus in his 'Vie de Saint Louis' (transcribed and edited in RHGF, 20, Paris, 1840, 64). Other medieval sources that reference the event include: the 'Grandes Chroniques de France', also known as a 'Chroniques de Saint Denis', found in multiple copies both illus trated and unillustrated, the earliest of which is London, British Library, Additional MS 38128 (trans cribed and excerpted in RHGF, 21, Paris, 1855, 116-117, and the art his torical focus of Anne D. Hedeman, The Royal Image: Illustrations of the Grandes Chroniques de France, 1274-1422, Berkeley CA,
} 
In the autumn of 1252 Blanche, by then 64, fell ill southeast of Paris at Melun and was hastily transported back to the capital. Upon her deathbed and in the presence of the Bishop of Paris, Blanche asked to receive the veil of the Cistercians and made a vow of obedience to the Abbess of Maubuisson, a measure that according to Terryl Kinder she had long intended to enact. ${ }^{36}$ She died either on 26 or 27 November and her body was prepared for procession, first by clothing it in the mantle of the order of Citeaux - effectively casting Blanche in the role of a simple nun - and then over it the Grand Mantle of France, with a sceptre and a small cross held in her hands and a golden crown on her head. Blanche was then placed, depending on the source, either upon 'une chaière d'or' or a flat bier, the latter favoured by artists imaginatively illustrating the event in later centuries (fig. 9). ${ }^{37}$ The funeral cortège then set off from the centre of Paris fronted by figures carrying crosses and trailed by mourners, stopping only at Saint Denis where Blanche lay in state overnight before travelling the final distance to Maubuisson the following day. ${ }^{38}$ Once arrived there, the queen's body was set up in the abbey church's choir, her veil was removed, and her head and chest anointed by the Archbishop of Rouen with holy oils. Finally, she was lowered into a space in the very centre of the church and covered with a gilded tomb that bore her likeness picked out in gold

1991); the 'Chronique Anonyme des Rois de France', preserved in Paris, Bibliothèque nationale de France, MS Français 8396.2 (transcribed and edited as 'Chronique Anonyme des Rois de France finis sant en M. CC. LXXXVI', in $R H G F, 21$, Paris, 1855, 83); the latter section of Matthew Paris' Chronica Majora, now bound as fol. 157-218 in London, British Library, Royal MS 14 C VII (transcribed and edited as 'Matthaei Parisiensis: Monachi Santi Albani, Chronica Majora' in Henry Richards Luard, ed., Rerum Britannicarum Medii Aevi Scriptores, 5, London, 1880, 354); the 'Journal des Visites' of Eude Rigaud, Archbishop of Rouen (transcribed in Théodose Bonnin, ed., Regestrum Visitationum Archiepiscopi Rothomagensis, Rouen, 1852, 150; the 'Chronico sanctae Catharinae de Monte Rotomagi' (transcribed and edited in RHGF, 23, Paris, 1894, 402); and the 'Gesta Sanctæ Memoriæ Ludovici' of Guillaume de Nangis (transcribed and edited in $R H G F, 20$, Paris, 1840, 384). Later sources include: Arthur de Bois lis le, 'Chambres des Comptes de Paris, 28 Sept, 1531', in Céremonial des Obsèques des Reines, 52, Nogent-le-Rotrou, 1873, 43-5; Charles de Combault, Blanche Infante de Castille, Paris, 1644; and Jean LeBeuf, Histoire de la Ville de Toutle Diocèse de Paris, Paris, 1754.

36 'Vidensquemortem imminere, corpus suum legavit ad sepeliendum domui sanctimonialium apud Ponteise'. Paris, Chronica Majora, 5, 345; Kinder, 'Blanche of Castile and the Cis tercians', 164.

${ }^{37}$ The golden chair is mentioned in the Grandes Chroniques. Combault adds: 'dans une Chaire. Ou plustost sur un Throne d'or, quel'onfit expres pour une si auguste ceremonie...', Combault, Blanche, 131.

${ }^{38}$ Paus ing at Saint Denis was presumably a political move designed to placate the monks there after the Queen's decision not to follow tradition and be buried in their choir. According to Alexandre Bande, herbody laying in stateby candlelight would have echoed that of Phillip Augustus, who had been similarly treated at Saint Denis in 1223 .

Alexandre Bande, Le Cour du Roi: Les Capétiens et Les Sépultures Multiples, XIIIe-XVe Siècles, Paris, 2009, 62. For the importance of such bodily dis play in contemporary French necrologies, see Charlotte Stanford, 'The Body at the Funeral: Imagery and Commemoration at Notre-Dame, Paris, 1304-18', Art Bulletin, 89: 4, 2007, 657-673. 
and enamel, a monument so large that the church's later Revolutionary inventors reported some 1.5 tonnes of metal removed during its destruction. ${ }^{39}$

We might, like the death of many medieval monarchs, expect that to be the end of the matter. But the most dramatic and, to the modern mind, most unsettling event in Blanche's interment took place some months later. For whilst the Queen had entrusted her body to Maubuisson, she had not done so in its entirety: her heart, she was clear, should be separated from her corpse and given to Maubuisson's sister institution, the abbey of Le Lys. ${ }^{40}$ Although similar acts of post-mortem bodily dispersal were later to rise to prominence, in mid-thirteenth-century France such a royal imposition had never before been requested. As Immo Warntjes' extremely detailed overview of the practice illustrates, reasons for bodily division - known at the time as dilaceratio corporis, literally the 'tearing' or 'rending' of the body - emerged through simultaneous practical, dynastic, and religious motivations. ${ }^{41}$ There was, after all, a serious problem of hygiene presented when any pre-modern

\footnotetext{
${ }^{39}$ The tombs and their arrangement in the church at Maubuisson, including a group of skeletons found in the chapter house, are attested by documents considered in Jean-Yves Langlois et al, 'Une Princesse Maudite jusque dans sa Sépulture? La Tombe Attribute à Blanche de Bourgogne (d.1326) dans le Chapitre de l'Abbaye Notre-Dame-La-Royale dite de Maubuisson', in Armelle Alduc-Le Bagousse, Inhumations de Prestige ou Prestige de l'Inhumation. Expressions du Pouvoir dans l'au-delà (IVe-XVe Siècle), Caen, 2009, 227-242, especially n.9-12. On Blanche's tomb, see:Dutilleux and Depoin, L'Abbaye de Maubuisson, 106, 171; Enamels ofLimoges: 1100-1350, exhibition catalogue, New York, 1996, 442, which suggests that its weight indicates a cast metal. A black marble tomb sitting today at Saint Denis has also been claimed as Blanche's, however this story is a later creation and has been debunked by several art historians, including Alain Erlande-Brandenburg in Le Roi est Mort: Étude sur les Funérailles, les Sépultures, et les Tombeauxdes Rois de Francejusqi 'à la Fin de XIIIe Siècle, Paris, 1975, 23, 114, 165, n.1, 2.

${ }^{40}$ Sébastien Rouillard, Histoire de Melun, Paris, 1628, 432-433. Rouillard cites several 'diverses chroniques et chartres manuscripts' thathe uses to create his detailed seventeenth-century account. Modern consensus places Rouillard as a reliable source: Gajewski, 'Blanche ofCastile', 217, n.73; Shadis, 'Piety, Politics, and Power', 212-3, n.68; Berman, 'Eleanor of Vermando is and Blanche ofCastile', 178; Erlande-Brandenburg, Le Roi Est Mort, 95. Immo Warntjes also tentatively sides with Rouillard, proving incorrect two previous readings that had cast some doubt on his testimony: the first in which Blanche is confused with her grand-daughter of the same name, whose viscera was buried at SaintCorentin-les-Mantes, and the second in a confusion of the Old French term 'cors', body and not heart, in a 1282 testament fromLe Lys. Immo Warntjes, 'Programmatic Double-Burial (Body and Heart) of the European High Nobility. Its Origin, Geography, and Functions', in Karl-Heinz Spieß and Immo Warntjes, eds, Death at Court, Wiesbaden, 2012, 222, n.74 and 223, n.76-79. See also Armande Gronier-Prieur, L'Abbaye Notre-Damedu Lys à Dammarie-les-Lys, Verneuil-l'Étang, 1971, 147.

${ }^{41}$ Warntjes, 'Programmatic Double-Burial', pres ents an extensive bibliography. Important works include: Estelle Weiss-Krejci, 'Heart Burial in Medieval and Early Post-Medieval CentralEurope', in Katharina Rebay-Salisbury et al, eds, Body Parts and Bodies: Whole Changing Relations and Meanings, Oxford, 2010, 119-134; Bande, Le Cour du Roi, 51ff; Danielle Westerhof, Death and the Noble Body in Medieval England, Woodbridge, 2008; Jean Nagle, La Civilisation du Coeur. Histoire du Sentiment Politique en France, du XIIe au XIXe siècle, Paris, 1998; Agostino Paravicini-Bagliani, 'La Papauté du XIIIe Siècle et la Renais sance de l'Anatomie', in Agostino Paravicini-Bagliani, Medicina e Scienze della Natura alla Corte dei Papi nel Duecento, Spoleto, 1991, 267-279; Brown, 'Death and the Human Body'; Walter Artelt, 'Die ältesten Nachrichten über die Sektion menschlicher Leichen im mittelalterlichen Abendland', Abhandlungenzur Geschichte der Medizin und der Naturwissenschaften, 34, 1940, 3-25; C. A. Bradford, Heart Burial, London, 1933.
} 
individual died far from their intended resting place. On 6 October 877, the Carolingian King Charles the Bald died in the Alpine town of Avrieux, whereupon his viscera including the heart were removed and buried, and his body stuffed with aromatic preservatives, salt, and wine to facilitate its intact return to the dynastic necropolis at Saint Denis. But so strong was the body's nauseous stench that the King's party could only take him as far as nearby Nantua where he was finally buried, his bare bones only returned to Paris seven years later after an expedition by a particularly devout and adventurous monk. ${ }^{42}$ This process became increasingly efficient and familiar amongst European royalty and it was maintained well into Blanche's era. On the death of her husband, Louis VIII, in 1266 in the Auvergne the king's body was divided up, his quick-rotting viscera removed and sent to nearby Saint-André de Clermont for burial while the remainder of the corpse was salted, wrapped in waxed cloth, and sewn into a cowhide for return to Paris. ${ }^{43}$ The body of Blanche's son, Louis IX, was also similarly treated when he died in 1270 on crusade in the African city of Tunis. His abdomen was eviscerated and his bones defleshed by boiling his corpse, preserving them for transport back to France. His heart was then given en route to his brother Charles in Sicily and buried in its own tomb at the Cathedral of Monreale in Palermo. ${ }^{44}$

Blanche, however, was the very first French royal figure to programmatically request the split burial of her body and heart while still alive. This could not have been an act of sanitised efficiency, for Blanche had lived almost all of her adult life in and around Paris and her body would not have had to travel far to any potential burial site. Instead, her reasons were at once spiritual and political. On the one hand, division of the corpse implied a clear statement of co-sanctity with medieval society's most divided bodies, the saints, whose relics had for generations been given proud and evangelatory delivery across Christendom. Non-saintly division was certainly problematic from a

\footnotetext{
${ }^{42}$ Warntjes, 'Programmatic Double-Burial', 206. For more on central Europe, see Estella Weiss-Krejci, 'Restless Corpses: "Secondary Burial" in the Babenberg and Habsburg Dynasties', Antiquity, 75, 2001, 769-780.

${ }^{43}$ For more on this affair, see Bande, Le Cour du Roi, 55-64.

${ }^{44}$ The prevalence of this crusader custom-sometimes cited in the sources as mos teutonicus, the 'Germanic custom' has been much discussed, specifically in Brown, 'Death and the Human Body' and also her 'Authority, theFamily and the Dead in Late Medieval France', French Historical Studies, 16:4, 1990, 803-832. On the practices of crusader surgeons more generally, seePiers D. Mitchell, Medicine in the Crusades: Warfare, Wounds and the Medieval Surgeon, Cambridge, 2004.
} 
theological point of view - so much so that in 1299 Pope Boniface VIII issued a bull condemning the practice - yet ecclesiastical disapproval seems not to have stemmed the dissective tide. ${ }^{45}$

Cistercian doctrine in particular had strongly internalised a growing thirteenth-century devotion to the body and heart of Christ, and foundations aligned to Citeaux were to become amongst the most frequent burial sites for bodies so dispersed. ${ }^{46}$ The canonisation in 1246 of Edmund of Abingdon, a favoured religious figure of Blanche, likely cemented in the queen's mind the heavenly potential of dividing one's body; Edmund had himself requested on his deathbed that his heart should be buried where he lay in the Augustinian house of Soisy-Bouy, but that the remainder of his body be returned to a resting place sixty miles away at Pontigny. ${ }^{47}$

On the other hand, followers of certain political regimes had for some time been utilising the dispersal of their ruler's bodies across various locations to emphasise a multiplicity of dynastic links. Englishmen of the twelfth century were particularly aware of the practice's power. The body of Henry I of England, for example, was split between Reading and Notre-Dame-du-Pré north of Rouen, a foundation of which he had been a key benefactor. As a contemporary epitaph at the latter site proudly attested, the English could cherish Henry's body and the French his innards, spreading the possibility of multiple royal remembrances throughout contested territories, forcibly linking them in memorialising union. ${ }^{48}$ The practice quickly became popular in aristocratic and royal classes of Plantagenet England and through noble circles spread to the French elite and finally to

\footnotetext{
${ }^{45}$ On the Church's attitude to bodily division and dissection, see: Warntjes, 'Programmatic Double-Burial', 224ff; Park, Secrets of Women, 42ff; and the still valuable Mary Niven Alston, 'The Attitude of the Church towards Dis section before 1500', Bulletin of the History of Medicine, 16: 3, 1944, 221-238.

${ }^{46}$ Literature on the religious, visual, and literary significance of the heart in the Middle Ages is extremely broad, but for a good summary see Heather Webb, The Medieval Heart, London, 2010. For the dissective potential inherent in religious practices of the heart, see Katharine Park, 'Relics of a Fertile Heart: The "Autopsy” ofClare of Montefalco', in Anne L. McLanan and Karen RosoffEncarnacion, eds, The Material Culture of Sex, Procreation, and Marriage in Premodern Europe, New York, 2002, 115-133.

${ }^{47}$ Blanche hers elf appears to have attended at least one of the two parts of Edmund's funeral. See Warntjes, 'Programmatic Double-Burial', 221.

${ }^{48}$ The epitaph reads: 'In tria partibus sua iura quibusqueresignat/Partibus illustrens sic tria regna tribus / Spiritui celum, cordi cerebroque dictata est / Neustria, que dederat Anglia corpus habet/Pars bona, pars melior, pars optima, pars sua cuique/Anglis Normannis, Celitbusque data est.' Bande, Le Cour du Roi, 53, n.11. On the long political history of doubling the royal body, see Ernst H. Kantorowicz, The King's Two Bodies: A Study in Mediaeval Political Theology, Princeton, 1997.
} 
Blanche. ${ }^{49}$ Granting the growing tradition French royal assent, she cannily split herself between not one but two of her favoured foundations. As Alexandra Gajewski puts it: 'By arranging for herself a burial suitable for a statesman or a saint, Blanche suggest that, if not her person, then the body politic could be as worthy of veneration as those already living with God'. 50

The decision by Blanche to have her heart buried separately from her body therefore seems politically ambitious and historically consistent. Yet the way in which this process was actually carried out is somewhat more complicated. Despite Blanche's dedication of the organ to Le Lys, the foundation's abbess, Blanche's cousin Alixe de Macôn, appears to have had some difficulty enforcing the queen's wishes. Only one source, a history of Melun reconstructed from documents originally held at Le Lys by the antiquarian Sébastien Rouillard, gives any hint as to the movements of the royal heart. ${ }^{51}$ In a detailed account, Rouillard records that Alixe did not in fact receive the previous viscera upon the queen's death, nor did she do so at her foundation south of Paris, but instead took charge of it in person at Maubuisson. Accompanied by the authority of Renaud de Corbeil, Bishop of Paris and Blanche's former confessor who had administered her last rites, it was only a full four months after the queen's funeral on 13 March 1253 that Alixe was granted the heart by Maubuisson, transporting it back to a now lost marble tomb in the choir at Le Lys. Given that by this point Blanche had been dead and buried for some time, how might such a translation have taken place?

\section{Opening B lanche}

In recent decades, significant strides have been made in reconstructing royal funerary practice in medieval and early modern France, especially with regards to processions, prayers, and tomb

\footnotetext{
${ }^{49}$ The first such recorded French burial is that of Amaury de Montford (d.1241). Blanche in turn seems to have spread the practice to royal dynasties in Spain and Italy. See Warntjes, 'Programmatic Double-Burial', 220-222, n.70, 224ff.

${ }^{50}$ Gajewski, 'Blanche ofCastile', 242-243.

${ }^{51}$ Rouillard, Histoire de Melun, 431-433. He des cribes the tomb as follows: 'Ce cour est sous une tombe de marbre soutenue dequatre piliers: et au-dessus est la state de cette Royne très illustre'.
} 
decoration. ${ }^{52}$ However, the toilettes funèbres - the process of preparing and embalming bodies for burial - is still often overlooked by art historians despite its regular contemporary conflation with various well-known objects of visual and material mortuary culture. The imagery of one fifteenthcentury manuscript for instance, again a Parisian product, makes clear how performances of embalming could be directly associated with funerary monuments (fig. 10). Here, an illustration accompanying the story of Alexander the Great's death and burial is reworked in twin parts as a contemporary French royal affair, with the body's postmortem treatment deliberately set into conversation with Alexander's memorialisation. Colourful attendant doctors gathered around the corpse are contrasted with attentive mourners around the grave, all in black; regnal accoutrements in life, gathered in the lower left, are paired with perpetual royal 'achievements' hanging high over the funerary scene to the right; and, most prominently, the figure of the opened Alexander laid out on a makeshift table - much like those featuring in contemporary anatomical imagery - is almost exactly echoed in his recumbent, gilded gisant. ${ }^{53}$

Lindy Grant states in her narration of Blanche's funeral that embalming would not have been necessary as the queen's body did not have far to travel. ${ }^{54}$ Yet this suggestion contrasts with a range of evidence recently gleaned by osteoarchaeologists and historians of medicine who note that anointing and embalming were fundamental processes of French royal funerals, events so deeply bound up with the ritual rhythms of burial that they would have been considered politically and theologically indispensable for the most revered corpse in the country at the time. ${ }^{55}$ More likely, to

\footnotetext{
${ }^{52}$ Murielle Gaude-Ferragu, D'Or et de Cendres. La Mort et les Funérailles des Princes dans le Royaume de France au bas Moyen Age, Villeneuve d'Ascq, 2005; Erlande-Brandenburg, Le Roi est Mort; Colette Beaune, 'Mourir Noblement à la Fin du Moyen Âge', Actes des Congrès de la Sociétédes Historiens Médiévistes de l'Enseignement Supérieur Public. La Mortau Moyen Âge, Strasbourg, 1977, 125-144; Ralph Giesey, The Royal Funeral Ceremony in Renaissance France, Geneva, 1960. On related Italian material, see: Park, 'The Life of the Corpse'; Sharon T. Strocchia, Death and Ritual in Renaissance Florence, Baltimore, 1992. On funerals of royal woman in particular, see Murielle Gaude-Ferragu, 'Des Femmes et la Mort: Sépultures et Funérailles des Reines et des Princesses au bas Moyen Âge', in Armelle Alduc Le Bagousse, Inhumations de Prestige, 383-404.

${ }^{53}$ The manus cript is now Paris, Bibliothèque nationale de France, MS Français 711. It contains Vasque de Lucène's Faits du Grand Alexandre, a French hybrid of earlier his tories of Alexander penned by Quintus-Curtius and Plutarch. I am grateful to Elly Truitt for drawing my attention to this image in her book Medieval Robots: Mechanism, Magic, Nature, and Art, Philadelphia, 2015, $106 \mathrm{ff}$.

${ }^{54}$ Grant, Blanche of Castile, 144.

${ }^{55}$ Phillipe Charlier and Patrice Georges, 'Techniques de Préparation du Corps et d'Embaumement à la Fin du Moyen Âge', in Bagousse, In humations, 405-438; Patrice Georges, 'Mourir C'est Pourrir Un Peu... Intentions et Techniques
} 
follow contemporary embalming technique, Blanche would have first been washed with water or perhaps with wine, a common ritual used doubly to cleanse and deliver the last unction. Thereafter, more invasive methods would have removed some of the queen's quicker-rotting internal viscera, the resultant cavities then filled with powders composed of various spices, plants, and salt, functioning as both antiseptics and desiccants that maintained the body's original shape. ${ }^{56}$ After being re-stitched, the mouth, nostrils, ears, anus, and genitals would have been either sutured or plugged to create a complete bodily seal, before being further anointed with various oils, including myrrh, camphor, salt, quicksilver, rosewater, and vinegar. Finally, the corpse was wrapped in a series of oilcloths, bandages, incense, and mastic, making sure to leave the face and hands exposed, ensuring the integral 'living display' of the deceased during procession.

What might have happened to Blanche's heart amidst such extensive preparations is in fact relatively clear. As Patrice Georges notes, unlike the treatment of the brain, encased in bone and leaving clear evidence of the extractive process, the specific removal of soft tissue and organs like the heart obviously leaves a less tangible archaeological trace. ${ }^{57}$ Still, the embalming methods noted at the time by Parisian surgical writers like Guy de Chauliac and his influential thirteenth-century predecessor Henri de Mondeville, agree that the heart would not have been affected by such procedures. Mondeville, who himself claims to have embalmed two kings of France - one of which was likely Blanche's great-grandson, Philip IV - suggests either a section of the lower abdomen should be cut out in the shape of 'an inverted shield', removing a triangular plate of flesh to allow access to the stomach and digestive entrails, or alternatively that a straight incision should be made along the abdomen from its middle down to the pubis, a short central line along which the two sides

Contre la Corruption des Cadavres à la Fin du Moyen Âge', Micrologus, 7, 1999, 359-382; Gaude-Ferragu, D'Or et de Cendres, 116-129.

${ }^{56}$ Phillipe Charlier, 'Evolution of Embalming Methodology in Medieval and ModernFrance', Medicina nei Secoli, 18: 3, 2006, 777-797; Charlier and Georges, 'Techniques de Préparation', 419-427; Gaude-Ferragu, D'Or et de Cendres, 108-129. These aromatic oils and spices also served to equate the deceased with the often miraculously sweet-smelling bodies of the saints, as well as accounts of the anointed dead Christ. See R. Corbineau and Patrice Georges 'Le Parfum de la Mort. Plantes et Aromates pour la Préparation des Corps', in Actes du Colloque 'Parfums et Odeurs au Moyen Age: Science, Usages et Symboles', Micrologus, 67, Florence, 2015, 161-180; Patrice Georges, 'Les Aromates de l'Embaumement Médiéval: Entre Efficacité et Symbolisme', Micrologus, 30, 2009, 257-268.

${ }^{57}$ Patrice Georges, 'L'Exérèse du Coeur dans l'Embaumement Médiéval Occidental', Micrologus, 11, 2003, 279-286. 
of the lower abdomen could be opened out. ${ }^{58}$ Visualisations of these techniques found in both a

1314 edition of Mondeville's Chirurgie and another treatise from a few decades later by the French royal surgeon Guido da Vigevano (figs 11 and 12), confirm that such cuts would have allowed the surgeon to access and remove the stomach's putrefying contents with ease; but in both cases further thoracotomy - incision in the upper chest - would have been necessary to access the heart, which remained deeper within the body, secured higher above the diaphragm beneath the largely unviolated ribcage. ${ }^{59}$

This medical evidence couples neatly with Rouillard's account of the documents at Le Lys that Abbess Alixe needed to travel the full distance to Maubuisson in order to reclaim the heart. No mention is given of the organ's extraction at the scene of Blanche's death, as is the case for some later medieval figures, nor is there any mention among the various accounts of the queen's funeral that it either accompanied her body separately in procession or was interred independently at Maubuisson alongside her tomb. ${ }^{60}$ In order for Alixe to have been satisfied, Blanche's heart would have needed to be reclaimed from beneath the grand gilded-copper effigy, perhaps even retrieved through the sagital slice that had been used to fill the queen with embalming spices some four months earlier.

Alone such an act of postmortem opening sounds extreme. Yet the possibility of a deeply dissective event like this taking place at Maubuisson is supported by factors beyond Rouillard's

\footnotetext{
${ }^{58}$ Mondeville's directions differ in the case of men and women: 'la paroi antérieure du ventre du milieu de la poitrine au pubis s'il agit d'un homme, chez les femmes on incisera de la fourche ou orifice de l'estomac en descendant suivant la forme d'un bouclier renversé jusqu'aux deuxflancs ou ilions; puis on renversera sur les parties sexuelles tout la paroi comprise entre les deux incisions et on extraira tous les viscères jusqu'àl'anus'. Henri de Mondeville, Chirurgie de Maitre Henride Mondeville, trans. and ed. Edouard Nicaise, Paris, 1893, 569. For the Latin see Julius Pagel, Die Chirurgie des Heinrich von Mondeville, Berlin, 1892, 390-393; for Chauliac's similar instructions, which reference Henri's techniques, see Guy de Chauliac, La Grande Chirurgie de Guy de Chauliac, trans. and ed. Edouard Nicaise, Paris, 1890, 437. Which specific kings Mondeville embalmed is not stated directly in his account. He was probably too young to have worked on Philip III in 1285 and was absent from Paris teaching anatomy in Montpellier in the years around 1304; most likely it was the bodies of Philip IV and Lou is X. For more on Mondeville, see Marie-Christine Pouchelle, Corps et Chirurgie à l'Apogée du Moyen-Age, Paris, 1983.

${ }^{59}$ For more on Vigevano, see Wickersheimer, Anatomies. These visualis ations come froman illustrated edition of Mondeville's text, now Paris, Bibliothèque nationale de France, MS Français 2030, fol. 29. See also Charlier and Georges, 'Techniques de Préparation', 422ff.

${ }^{60} \mathrm{See}$, for example, the account of the removal of Jean Duke of Berry's heart in Françoise Lehoux, 'Mort et Funerailles du Duc de Berri (Juin 1416)', Bibliothèque de l'École des Chartes, 114, 1956, 76-96. For individuals whose hearts do receive separate funerals, see Murielle Gaude-Ferragu, 'Le Cœur "Couronné": Tombeauxet Funérailles de Coeur en France à la Fin du Moyen Âge', Micrologus, 11, 2003.
} 
word alone: it is bolstered by the abbey's objects. For one thing, this matter of the heart returns us directly to the foundation's Shrine Madonna, perhaps commissioned by Blanche herself, and its figural intertwining at the abbey of anatomy and aesthetics. Both Blanche's corpse and the Madonna's wooden body stand as openable forms whose anatomical readings are mutually enforced in light of their shared corporeal context. Blanche, viewed through the model of her foundation's Shrine Madonna, was a royal corpus made almost invincible by comparison. It too was a maternal body that could, like a sculpture, withstand being opened and shut in search of a heart without the ultimate destruction of its subject, for its subject - elevated by royal status and pseudo-saintly division - was already with God. Meanwhile the Shrine Madonna, viewed through Blanche, was a sculpted body granted a fresh fleshly presence. Arguments against reading a literal corporeality into such sculptures cite the troubling violence that their opening would create if done unto a real human form. And yet here in the church at Maubuisson we potentially find just such a comparable anatomical engagement with an actual body, an intervention in equal parts ritualised and medicalised. The enthroned Queen of Heaven and the interred Queen of France were both bodies with the same underlying mechanics: they could be opened, refigured into a world of inverted innards, and later closed and regathered into their original singular state, unscathed.

What is more, if we continue to track Maubuisson's bodies we discover that anatomical urges at the foundation extend well beyond this singular pairing. Far from an embarrassing corporeal footnote in the foundation's history, Blanche was formed into an anchor for future generations of bodily investigation and display at Maubuisson. Her excavation was not something merely to be remembered in the abstract: it offered the institution a pervasive conceptualisation of anatomical memorial that was to recur over a much longer history, both in the visual choices of the abbey's future patrons and the behaviour of its future residents. 


\section{Royal Entrails}

In the two centuries following Blanche's death, over 30 other figures of the French royal family were to undergo programmatic double-burial, spreading their bodies far and wide for reasons of practicality, politics, and, by this stage, a tradition initiated by the thirteenth-century queen (fig. 13). Maubuisson continued to play a key part in this process and it was not long before other members of the royal household began being interred there. ${ }^{61}$ In 1271, Blanche's son, Alphonse of Poitiers, was laid to rest in a marble mausoleum not far from his mother. Jean de Brienne, the socalled Prince of Acre and cousin to Louis IX, was interred there soon after his death in 1296 in a gilded-copper box mounted with the gisant of a knight. Robert II Artois, Blanche's grandson, died in July 1302 and was buried at Maubuisson the following December, followed soon after by his own daughter Mahaut in 1329. Blanche's tomb, complete with her gilded likeness atop it, functioned as a dynastic lynchpin at the epicentre of the abbey's church.

Yet the tomb's presence was also to function as a reminder of the controversial events of 1253, an operating table dropped into the choir. It was not simply that other members of Blanche's royal family wished to be buried at Maubuisson; it is significant what parts of them they wished buried there. Alphonse, for example, had died en route to France while returning from the crusade of the 1270 s and although his bones were sent to the official royal necropolis at Saint Denis, he had stipulated that his heart and entrails should be removed and sent to Maubuisson to reside with his mother's body. ${ }^{62}$ The will of King Charles IV records that he earned specific permission from Pope John XXII in a Papal Bull of 3 July 1322 to have his corpse trisected: his body was to be sent to the royal 7ecropolis at Saint Denis, his heart to the Dominican friars of Paris, and his entrails to

\footnotetext{
${ }^{61}$ For a full list of those known to be interred at Maubuisson, see Dutilleuxand Depoin, L'Abbaye de Maubuisson, $106 \mathrm{ff}$.

${ }^{62}$ 'Gesta Sanctæ Memoriæ Ludovici', 488. See also:Bande, Le Cour du Roi, 68; Erlande-Brandenburg, Le Roi est Mort, 78.
} 
Maubuisson, a three-part division enacted on his death in $1328 .{ }^{63}$ In the 1370 s, Charles' wife and long-time widow, Jeanne d'Évreux, also requested identical treatment to her husband. ${ }^{64}$

Taking up Blanche's anatomical gauntlet in Maubuisson's growing necropolis, these royal figures also sought to conflate the dividing up of their bodies with the objects of their commemoration. Shortly before her death, Jeanne commissioned the sculptor Jean de Liège to create a double tomb for the entrails of herself and Charles, the upper sections of which were somehow spared destruction in the Revolutionary dismantling of Maubuisson and bought by the Société des Amis de Louvre in January 1907 (fig. 14). ${ }^{65}$ In these two marble gisants, Jeanne and Charles are shown around half life-size, both crowned, lying recumbent, and dressed in typically sculpted royal robes with fashionably pointed shoes poking out from beneath swathes of cloth. But clutched prominently at their hearts are also two sculpted leather-skin bags, each of which realistically mould around neat coils of intestine gathered inside them, curled up in circular strips like links of sausages. Depicted in unsettling detail, they make crystal clear to the viewer that it was the couples' viscera and not their full bodies that was to be found enclosed within the tomb. Doubtless prompted by his royal predecessors, King Charles V's will of 1374 requested a similar tripartite division between Saint Denis, Rouen Cathedral, and Maubuisson. ${ }^{66}$ His wishes were enacted upon his death in 1380 and across the choir from the nearby gisants of Jeanne and the earlier Charles another entrail tomb was installed sporting a kindred inverted effigy commissioned of Jean de Liège, a purse of marble guts sculpted at yet another royal figure's chest (fig. 15).

\footnotetext{
${ }^{63}$ The will reads: '... mon corps soit divisé en troisparties: c'est assavoir quantau cuer et quant aux entrailles. Quant au corps je eslis ma sépulture au couvent des frères precheurs de Paris et est ma dernière volonté que quelque part que Dieu fasse sa volonté de moi, que mon corps soit apporté à Saint-Denis en Franceet mon Cour au couvent des frères prescheurs de Paris... quant à mes entrailles je eslis ma sépulture au couvent des nonnais de Maubuissonjouxte Pontoise, si je trespassois si près que l'on les y peut apporter convenablement et si je trespassois si loin que l'on ne peut les apporter convenablement je veux et ordonne que en ce cas mes entrailles soient mises en terreau plus proche couvent de l'ordre des frèrs prescheurs...'. On the Papal Bull, see Bande, Le Cour duRoi, 94, n.111.

${ }^{64}$ Bande, Le Cour du Roi, 95.

${ }^{65}$ On Jean de Liège, see: Françoise Baron, 'Autour de Jean deLiège et de Thomas Privé', Bulletin de la Société Nationale des Antiquaires de France, 1989, 311-319. On Jeanne's architectural patronage, see Carla Lord, 'Jeanne d'Évreux as founder of Chapels', in Cynthia Lawrence, ed., Women and Art in Early Modern Europe: Patrons, Collectors, and Connoisseurs, University Park, 1999, 21-36.

${ }^{66}$ Bande, Le Cour du Roi, 17-37.
} 
By the late fourteenth century these increasingly abdominal Capetian memorials were the largest objects in abbey's church (fig. 16). In part their commissioning was another pseudo-saintly move by the Maubuisson royals, for if a medieval viewer was to be familiar with graphic entrail depictions it was likely through hagiographic imagery. As Alison Stones has shown, images of eviscerated martyrdoms were often to be found in French manuscript painting at the time, and at least eight different saints entérophores - figures whose iconography depicted them walking miraculously whilst presenting their splayed innards - can be identified across medieval and early modern France. ${ }^{67}$ Sculptures like the fourteenth-century polychromed stone likeness of Saint Mesmin, recorded at the church of Sainte-Foi at Jouy-Mauvoisin just west of Maubuisson, also suggest the strong visual links these gutless saints held with the nearby abbey tombs; like many of his enterophoric contemporaries, Mesmin is described as standing with his arms at his belly, part clutching and part presenting similarly rendered coils of intestines that push through a vertical slit in his long robes. ${ }^{68}$ That an audience existed in the Middle Ages to receive these anatomical connections, especially in artistic circles, is further indicated by the cross-pollination of artisans between Maubuisson and the Cathedral of Saint-Mammès at Langres, a patron saint who was himself often depicted eviscerated. Evrard d'Orléans, who sculpted Maubuisson's now-lost tomb of Robert II Artois and an altar retable gifted to the abbey by Jeanne d'Évreux, also created a sculpture of Mammès for the cathedral at Langres, one of many stone, wood, and ivory figurines that depicted him miraculously displaying his entrails to the faithful (figs 17 and 18). ${ }^{69}$ All of this visceral religious imagery was also almost certainly drawing on contemporary medical illustrations for

\footnotetext{
${ }^{67}$ Alis on Stones, 'Nipples, Entrails, Severed Heads, and Skin:Devotional Images for Madame Marie', in Colum Hourihane, ed., Image and Belief: Studies in Celebration of the Eightieth Anniversaryof the Index of Christian Art, Princeton, 1999, 47-70. Roland Vas seur, 'Saint Mesmin l'Entérophore', Bulletin de la Société 'Les Amis du Mantois', Mantes-la-Ville, 1977, 3-14. Vassuer lists several local saints entérophores: Erasmus, Mammès, Wulmer (sometimes Wilmer or Vimer), Mexme de Chinon, Émérantienne, and the Breton saint Mamert (sometimes Mémor).

${ }^{68} \mathrm{~A}$ tradition at Jouy-Mauvoisin, recorded as late as the 1910s, notes the sculpture as holding long entrail-like ribbons that were collected by local congregants in times of sickness. See Vas seur, 'Saint Mesmin', 4.

${ }^{69}$ Henry Ronot, 'Une Sculpture Inédite d'Évrard d'Orléans: Le Saint Mammès de la Cathédrale de Langres (1341)', Bulletin de la Société de l'Histoire de l'Art Français, 1953, 17-19. On Orléans and the Capetians, see Gerhard Schmidt, Gotische Bildwerkeundihre Meister, Vienna, 1992, 59-71. On Maubuisson's altar and Jeanne's patronage see Michele Tomassi, 'La pala d'altare di Maubuisson: note sull'iconografia', in Maria Monica Donato and Massimo Ferretti, eds, Conosco un ottimo storico dell'arte: Per Enrico Castelnuovo, Scrittidi allievi e amicipisani, Pisa, 2012, 125-130 (and the bibliography therein).
} 
inspiration, where the identical spiralling entrails of both man and beast had become common features of curative manuscripts from across Europe, advising on everything from anatomical structure to balanced diet (figs 19 and 20). ${ }^{70}$ Exuding from Blanche at the centre of the choir were the dissective results of her dynastic Dilaceratio corporis, all the while watched over from the altar by the split Shrine Madonna.

Not only did Maubuisson's royal tombs have actual anatomised contents contained within them and anatomies modelled into their effigies above, but their corporeality was also clearly avowed through public text. Adolphe Dutilleux and Joseph Depoin's 1882 study of the abbey church's interior pieces together the substantial epigraphic evidence at Maubuisson, with viscera featuring prominently amongst their short verses. ${ }^{71}$ Carved into the black and white marble slabs of the tombs, and in some cases picked out in inlaid gold or gilded copper to catch the light, they constantly attested to the church's bodily contents: 'Here lies the heart and the entrails of Alphonse'; 'Here is interred the entrails of King Charles... the entrails of Madame Jeanne d'Évreux'; 'Here lies the excellent and noble Bonne of Bohemia, and with her interred the entrails of her son Charles'. ${ }^{72}$ With these monuments, inverted anatomy was quite literally written into Maubuisson's material history and collective memory.

\section{Anatomical Legacies}

The abbey fared with mixed fortunes beyond the Middle Ages. The sixteenth and seventeenth centuries saw Maubuisson survive France's religious wars and although it was sacked by protestant Huguenot forces it continued to function as a religious house with a strong tradition of aristocratic

\footnotetext{
${ }^{70}$ The images reproduced here are froma Latin edition of Ibn Sina's Canon(Italy, 1300-1310, now Vatican, Biblioteca Apostolica Vaticana, MS Urb. Lat. 241, fol. 246v) and an edition of the Tacuinum sanitatis (Germany, fifteenth century, now Paris, Bibliothèque nationale de France, MS Latin 9333, fol. 71r).

${ }^{71}$ Dutilleux and Depoin, L'Abbaye de Maubuisson, $107 \mathrm{ff}$.

${ }^{72}$ In the original French: 'Icy reposele Cour et les entrailles d'Alphonse comte de Poitiers, frère du Roi Louis... '; 'Icy sont enterrés les entrailles du Roi Charles... et les entrailles de Madame Jeanne d'Évreux... '; 'Cy gist très excellente et très noble Dame Madame Bonne de Bohême... de lez laquelle sontenterrées les entrailles de son dit fils Charles...'.
} 
burial. In 1599, the controversial mistress of Henry IV, Gabrielle d'Estrées, was buried in the church choir, as were two of the foundation's abbesses who were themselves drawn from the nobility: Louise Hollandine (d.1709), daughter of Frederick V of Bohemia, and Charlotte-Elizabeth of Bavaria (d.1722), second sister of Louis XIV. ${ }^{73}$ Louise and Charlotte-Elizabeth both took up the long tradition, not at all uncommon in the medieval or early modern convent, of full-body burial within the church they had once commanded. But the anatomical legacy of medieval Maubuisson propelled at least one later inhabitant into more drastic obedience. On 23 August 1692, MarieSylvie Brabantine de Trémoille, a noblewoman and daughter of Henri-Charles, Prince of Taranto, and Emelie, Princess of Hesse, died in Paris. She had been brought up at Maubuisson between the ages of 4 and 17, and on her death she bequeathed various possessions to her alma mater. Most were not atypical: her Parisian home, her library, and many of her valuables were all left to Maubuisson in her will. ${ }^{74}$ But she also requested that her heart should be removed from her body and brought to the abbey for burial. A day after her death, and with no recorded pomp or circumstance, the incumbent Abbess Marie Louise had the organ transported there and buried in the nave within a tomb of white marble. Yet another anatomical inscription was stamped upon Maubuisson: 'Here lies the heart of Marie-Sylvie Brabantine de la Trémoille'. ${ }^{75}$ By this point in the early modern period programmatic double-burial was centuries out of fashion in France; the most recent royal to enact it died more than a century before Marie-Sylvie. And of course by the turn of the eighteenth century Parisians had an almost unrecognisably different bodily outlook to their thirteenth-century compatriots. Enlightenment understandings of anatomy and the body in relation to the soul, spirit, and mind had challenged and reworked the now archaic-seeming medieval practice of dividing the corpse. ${ }^{76}$ That Marie-Sylvie should have wanted her heart removed can only

\footnotetext{
${ }^{73}$ Dutilleux and Depoin, L'Abbaye de Maubuisson, 109ff.

${ }^{74}$ Dutilleux and Depoin, L'Abbaye de Maubuisson, 116.

75 'Icy repose le cour de Marie-Sylvie Brabantine de la Trémoille... '.

${ }^{76}$ On enlightenment shifts, see for example: Kathleen Adler and Marcia Pointon, eds, The BodyImaged: The Human Form and Visual Culture since the Renaissance, Cambridge, 1993; Barbara Maria Stafford, Body Criticism: Imaging the Unseen in Enlightenment Art and Medicine, Cambridge MA, 1991.
} 
be put down to a clear tradition at Maubuisson, the unusual memorialising of bodily inversion continuing to pervade the foundation.

These continuing early modern anatomical rituals at Maubuisson were as much about flamboyant performance as they were quieter, more humble, contemplative commemoration like that of Marie-Sylvie. In May 1652 abbey records show a major reconfiguration of its church's tombs and as part of this renovation the medieval sepulchre of Robert II Artois, in which he had originally been buried on 15 December 1302 , was due to be relocated from one part of the choir to another. ${ }^{77}$ However after breaching the wall into which Robert's tomb was set, an unmarked, leadlined box was unexpectedly discovered. Upon opening it was found to contain the count's threehundred-year-old entrails, miraculously un-decayed and described as 'fresh, vermillion, and fullbloodied' ${ }^{78}$ To mark the occasion, the viscera were displayed exposed in the church for 10 weeks for the benefit of 'both the faithful and the curious', all the while exuding a soft, sweet smell and never dulling in colour, before eventually being placed back into their casket and reinterred. ${ }^{79}$ Well into the seventeenth-century, Maubuisson's occupants were gutting the walls and proudly displaying their foundation's miraculous innards.

Coincidentally, it is at precisely the same moment as Robert's entrails were being unfurled from the stonework that the Maubuisson Shrine Madonna reappears in the historical record in the first-hand account of Soeur Candide, who notes its presence in the foundation's liturgical life despite decades of neglect. Her narrative is is essentially a short story of hierarchical in-fighting between the recently-arrived Abbess Suireau and the residing Fathers, but it pauses to wax poetical about the Shrine Madonna. 'When she was open', Candide begins, 'she was not a Virgin but a world and more than a world'. ${ }^{80}$ We learn too of the sculpture's poor condition: by the midseventeenth century it was considered old ('de vieillesse'), and was showing the effects of the

\footnotetext{
${ }^{77}$ Dutilleux and Depoin, L'Abbaye de Maubuisson, 107-8.

78 ،... fraiches, vermeilles et encore toutes sanglantes'. This testimony comes from the magis trate and historian PaulFrançois Pihan de la Forest, cited in Dutilleuxand Depoin, L'Abbaye de Maubuisson, 108.

${ }^{79}$ Dutilleux and Depoin, L'Abbaye de Maubuisson, 108.

${ }^{80}$ 'Quand'elle estoit ainsi ouverte, ce n'estoit une Vierge, mais un monde et plus qu'un monde...'. Here I follow Candide's testimony as cited in Depoin, 'La Vierge Ouvrante'.
} 
previous centuries, rotting and riddled with so much woodworm ('tout vermoulu') that one could not touch its interior figures without reducing them to dust. ${ }^{81}$ Candide reports that her abbess remained concerned that the figure could fall, damaging the high altar or even killing someone, and - especially poignant for a bodily reading of the sculpture - that the Madonna's central partition was considered fundamentally 'indecent' by the Mother Superior. ${ }^{82}$ For both reasons the abbess wished the figure to be taken away from where it sat behind the altar alongside 'a belt of great statues of kings, queens, princes, and princesses of France', Maubuisson's royal entrail gisants which still flanked the choir. Eventually placated by other members of the community, the abbess relented and the Madonna was instead moved to a side chapel within the smaller winter choir, allowing Maubuisson's nuns the freedom to observe, as Candide puts it, the 'little worlds enclosed inside the body of the monstrous figure'. ${ }^{83}$ From here the Madonna's opening and closing continued to have a palpable bodily resonance, surrounded by the continued fascination at Maubuisson for revealing the wonders of the human interior. With Marie-Sylvie's freshly delivered heart and Robert's unearthed innards both interred but a few metres away, the repeated revelation and reconcealment of the Madonna's sculpted body again takes on a renewed potency. Shifting away from a meditative and solely spiritual act, opening the Shrine Madonna was once more confirmed as a performance of anatomical confraternity with the multiple individuals that Maubuisson had already flipped inside-out.

\section{Closing}

Dwindling to a total of only 18 cloistered nuns by 1780 , Louis XVI officially closed Maubuisson in 1786, but this did not spare the abbey from the excesses of the Revolution. The church itself was systematically dismantled, with guards removing fittings and furniture for

\footnotetext{
81 '....si délicates et si vieilles qu'onn'y pouvoit toucher sans les réduire en poussière...'.

82 ،... en tombant endommager le grand autel et tuer quelqu'un'; 'cette fente au milieu du corps, qui estoit indécent...'.

83 '.... avoient plus de liberté à se divertir à considérer les petits mondes enfermez dans le corps de cette monstrueuse figure'.
} 
destruction or sale and finally forcing the remaining inhabitants from their quarters in February 1793. Blanche's tomb was melted down and the royal entrail gisants sold or stolen. The church building itself was considered detrimental to the value of the land, and revolutionary entrepreneurs razed it to the ground in January $1798 .{ }^{84}$ The very walls inside which Robert's entrails had been reconcealed were demolished.

The fate of the Maubuisson Madonna, however, was somewhat more fortunate, a concluding episode in the foundation's history that adds a neat anatomical full stop. Sensing the political tide, those remaining at the abbey smuggled the prized sculpture from the church just before its dissolution and destruction. Entrusted into the care of the foundation's gardener, Guillaume Chennevière, it was kept in a secret cupboard in the corner of his family home, sitting out France's Revolutionary iconoclasm for almost a generation. In 1839, however, the indiscretion of one of Guillaume's grandchildren revealed the whereabouts of the sculpture to the curate of the nearby parish at Saint-Ouen-l'Aumône, one M. Brétinière, who demanded its speedy removal and installation in his church. ${ }^{85}$ Arriving there on 15 October 1839, perhaps the sculpture's procession from the gardener's residence matched its medieval parading around the streets of Pontoise or the pomp of Blanche's own posthumous royal return to Maubuisson. Certainly once inside the church, something of the abbey's ceremonial surrounding the sculpture was reclaimed. The first Sunday after its discovery, in front of a large congregation of the parish's donors and patrons, the Madonna was opened. One can only imagine the sight that beheld them. The sculpture had been kept closed since 1792, where upon instruction from the nuns who entrusted it to him the gardener Chennevière had nailed the Madonna's two wings shut with a horseshoe atop her head. With the dilapidated inner figures described even in Candide's time as crumbling to dust, it would not have been the most pleasant unveiling. Sealed shut, kept in a kitchen cupboard for nearly fifty years, and riddled with woodworm for at least two hundred, the fragile interior would have resembled less a heavenly

\footnotetext{
${ }^{84}$ Odile Vergé DuTaillis, Chroniques de l'Abbaye Royale de Maubuisson: 1236-1798, Paris, 1947, 233ff; Kinder, 'Blanche ofCastile', 168.

${ }^{85}$ Depoin, 'La Vierge Ouvrante', 7-9.
} 
body than the decaying interior of a human one, its crumbling innards un-preserved and decomposing. The disagreeable sight which befell the assembled congregation is made clear by the process-verbaux of the presentation meeting, which concludes with a speedy decision to have the interior restored. ${ }^{86}$ And yet the account also preserves a remarkably similar sense of wonder to that evoked by Soeur Candide: 'we found', the minutes note, 'that the interior's workman ship was at once singular and mysterious... the life of the Saviour enclosed within the womb of his saintly mother' ${ }^{87}$ Repaired by a local craftsman, the sculpture was placed in the southern side chapel of the small church (fig. 21). Designated a protected national Monument Historique in 1897, it remained poised for opening whenever the worship of this new congregation so desired, and it was from this chapel that the sculpture was ultimately stolen in 1973, shut to all for good.

Art historians always champion the power of objects to reveal histories beyond the aesthetic. But what this long view of Maubuisson and its objects demonstrates particularly well is the ability of certain medieval spaces to act as conceptual echo chambers, amplifying through accumulation the commonalities of bodies, events, and artworks. Resounding at Maubuisson was a disregard for corporeal boundaries, one which birthed a novel form of individual anatomical memorial that soon regularised into a practice of inherited recollection and remembrance. There, ongoing events were

\footnotetext{
${ }^{86}$ 'La piété des fidèles nous a mis à même de la restaurer; nous l'avons remise, nous pensons, en l'étatoù elle était lorsqu'elle vintà Maubuisson'. Depoin, 'La Vierge Ouvrante', 15 . So dilapidated was the interior that in order to recons truct the scenes the Curé Brétînière sought out two elderly women whomhe thought to be former nuns of Maubuisson. These women had supposedly fled the Revolution to the Ottoman Empire and their recollections aided the restoration. Unfortunately, as Depoin notes, Revolutionary records suggest that there were no young nuns present at Maubuisson at the time of the church's destruction in 1792, the youngest being born in 1749; that Brétînière's 'nuns', interviewed nearly a century later in 1840 , were true eye-witnesses of the sculpture is unlikely. The choice and style of the restoration was more probably the Curé's own, perhaps taking note of what remained of the original rotted interior. Melissa Katzclaims the sculpture was restored between 1792-1839 at the Louvre, although this was precisely the period when according to Depoin the sculpture was in hiding. See Melissa R. Katz, 'The Non-Gendered Appeal of Vierge Ouvrante Sculpture: Audience, Patronage, and Purpose in Medieval Iberia', in Martin, Role of Women, 90, n. 88 and 89 .

87 'Nous avons trouvé, dit le rédacteur, que l'intérieur étaitd'un travail tout à la fois singulier et mystérieux... la vie du Sauveur, renfermée dans le sein de sa sainteMère'. Depoin, 'La Vierge Ouvrante', 14.
} 
conflated with a continued bodily curiosity to form a foundation-wide mode of local identity and institutional memory.

Extending art history's renewed focus on materiality into the medical realm, Maubuisson brings to light a new and distinctly anatomical context with which we might begin to read medieval objects. And at the same time, as with Jean de Roi's story of the franc-archer with which I began, the abbey's unusual bodily topography might also be reflected back onto our medical understanding of this late medieval and early modern moment, offering a parallel material account of anatomical engagement beyond the treatises of practitioners or the statute books of universities.

Complementing the narratives we intuit from larger civic systems like Paris, where the medicalised body might be revivified through text alone, Maubuisson offers a case study in the neat folding together of contemporary medical concept, deeply-felt religious ritual, and sculpture.

Today, the abbey church is grass and daisies. Yet anatomical fascination continues apace. In 2004, a decision was made by the local council to turn part of the foundation's lone standing building into a contemporary art gallery and in 2009 it played host to an exhibition of the controversial French artist ORLAN, best known for the drastic surgical reconfiguration of her own body and her pseudo-religious alter-ego, Saint-ORLAN. ${ }^{88}$ Seemingly unaware of the long tradition of sanctified, medicalised, and concealed figures at Maubuisson, a group of ORLAN's sculptures were displayed in the abbey's restored refectory. Entitled Bodiless Garment: Fold Sculpture (19832009), they re-conceive the now anonymous nuns who once inhabited the space of the medieval foundation, three swirling cyclones of unfolding, inverted drapery in black, white, and gold (fig. 23). They aptly speak to Maubuisson's medieval and early modern history, a place where extreme practices of the body have always been comfortably entangled, constantly opening and closing into the past.

\footnotetext{
${ }^{88}$ Unions Mixtes, Mariages Libres et Noces Barbares: Une Expositiond 'ORLANà l'Abbaye de Maubuisson, exhibition catalogue, 30 September 2009-8 March 2010, n.p. On Orlan's work more generally, s ee C. Jill O'Bryan, Carnal Art: Orlan's Refacing, Minneapolis, 2005.
} 